\title{
Seroprevalence of varicella antibodies in adults without clinical history of disease
}

\section{Soroprevalência de anticorpos antivaricela em adultos sem história clínica da doença}

Seroprevalencia de anticuerpos frente a la varicela en adultos sin historial clínico de la enfermedad

\author{
Konrad Silva Büchele 1 \\ Danusa Ferreira Correa 2 \\ Mari Tuyama 2 \\ Alberto dos Santos de Lemos 2 \\ Marcellus Dias da Costa 2 \\ Emersom Cicilini Mesquita 2 \\ Daniel Marinho da Costa 2 \\ José Cerbino-Neto 2 \\ Margareth Catoia Varela 2 \\ Pedro Emmanuel Americano Alvarenga do Brasil 2 \\ Luciana Gomes Pedro Brandão 2
}

\begin{abstract}
Varicella in adults and immunocompromised patients can be severe. The clinical diagnosis of varicella has high accuracy and the history of disease has a high positive predictive value for protection. A significant portion of adults, however, cannot remember if they have had varicella, especially older individuals. We conducted a cross-sectional study to determine the seroprevalence of varicella protective antibodies titers in adults with no clinical history of disease, attended at a Reference Center for Special Immunobiologicals and Travel Medicine in Rio de Janeiro (Brazil). Titration of immunoglobulin $G$ (IgG) antibodies to varicella-zoster was determined by chemiluminescence immunoassay. Among 140 adults without history of varicella, 92\% had protective antibody titers. We concluded that seroprevalence of varicella-zoster protection was very high in adults with negative history of disease and the use of serology before vaccination reduced significantly unnecessary vaccine and immunoglobulin use.
\end{abstract}

Varicella; Adult; Seroprevalence; Vaccines

\section{Correspondence}

L. G. P. Brandão

Laboratório de Pesquisa em Imunização e Vigilância em Saúde, Instituto Nacional de Infectologia Evandro Chagas, Fundação Oswaldo Cruz.

Av. Brasil 4365, Rio de Janeiro, RJ 21040-900, Brasil. luciana.pedro@ini.fiocruz.br

1 Hospital Naval Marcílio Dias, Marinha do Brasil, Rio de Janeiro, Brasil.

2 Instituto Nacional de Infectologia Evandro Chagas, Fundação Oswaldo Cruz, Rio de Janeiro, Brasil. 


\section{Introduction}

Varicella is an acute infectious disease caused by varicella-zoster virus, a human alphaherpesvirus 1. The disease is more frequent in children aged 1 to 10 years; nevertheless, it can occur in susceptible people of any age. In most cases, especially in healthy children, it is often a mild disease, with a lethality rate of 1 to 4 in 100,000 cases. Adults and immunocompromised individuals are at higher risk of serious complications and death 2. The lethality rate in adults is about 25 times higher 3,4,5.

Varicella-zoster virus is highly transmissible. The secondary attack rate among susceptible household contacts can be up to $90 \% 3$. Virus transmission occurs primarily by respiratory secretion (saliva droplets, sneezing, coughing) of an infected individual or by direct contact with the vesicle fluid. In Brazil, varicella is not a disease of mandatory notification, although outbreaks need to be reported. In 1997, a study on blood donors from five Brazilian capitals showed a high prevalence of anti-varicella immunoglobulin G (IgG), 89\% in Salvador and Fortaleza and 97\% in São Paulo, Curitiba and Porto Alegre, denoting the high probability of natural immunity to varicella among adults in the Brazilian population 4.

Varicella is a preventable disease. A significant reduction in varicella incidence and death rates can be observed at countries that adopted routine vaccination ${ }^{3}$. In Brazil, the varicella vaccine has been used since 2000 at Reference Centers for Special Immunobiologicals (CRIE) for vaccination of individuals with special need. In September 2013, varicella vaccine was introduced at the National Immunization Program (PNI), being freely available for all children aged 15 months (1 dose) 6. In 2018, the Ministry of Health introduced the second dose for children aged 4-6 years old 7 .

Eligibility to varicella vaccine and immunoglobulin at CRIE includes susceptible individuals of all ages in special circumstances: health professionals, household contact of immunocompromised patients, candidates for solid organ transplant, patients with chronic renal disease, HIV, severe dermatologic diseases, asplenia, trisomy, bone marrow transplantation (after 24 months), donors of solid organs or bone marrow. Eligibility to varicella immunoglobulin at CRIE includes susceptible individuals with high risk of severe disease that had significant contact with a patient with varicella-zoster and has contraindication to live-attenuated vaccine (pregnancy, immunosuppression, hospitalized children $<1$ year of age, newborn) 8 .

The clinical diagnosis of varicella has high accuracy and the history of disease has a high positive predictive value for protection ${ }^{9}$. A significant portion of adults, however, cannot remember whether they have had varicella, especially older individuals. In these circumstances, individuals with no clinical history of varicella are considered susceptible and eligible for vaccination or immunoglobulin at CRIE, according to the criteria defined by Brazil's PNI (Ministry of Health).

Our objective, in this study, was to determine the seroprevalence of varicella protective antibody titers in adults considered susceptible (based on clinical history), who were candidates for immune prophylaxis at a public reference immunization center in Rio de Janeiro (Brazil). Travelers attended at the Travel Medicine Clinic were also included at the study. Although they were not eligible to receive varicella vaccine at CRIE, serology is usually part of pre-travel consultation, when the traveler has no clinical history of varicella and has not been vaccinated. Susceptible travelers were oriented to receive the vaccine at private clinics.

\section{Material and methods}

We conducted a cross-sectional study, between January 2013 and December 2017, at CRIE and at Travel Medicine Clinic from the National Institute of Infectious Diseases Evandro Chagas, Oswaldo Cruz Foundation (INI/Fiocruz) in Rio de Janeiro.

All adults who had no history of varicella or zoster were systematically invited to participate in the study. After written inform consent, a standardized questionnaire with information about personal and family history was completed. Data collected included age, sex, living in rural area at infancy, number of siblings, number and age of children, if children had varicella, condition for indication of immune prophylaxis to varicella in CRIE. In all participants, a blood sample was collected to varicellazoster serology (chemiluminescence method, Liaison VZV IgG). Individuals with antibody titers > 
$150 \mathrm{IU} / \mathrm{mL}$ are considered protected for varicella. The covariates distribution according to varicella protection were tested with either student's t-test, Pearson chi-squared test or Fisher exact test. The choice of the test was based on the covariate format (categorical vs. continuous) and if the smallest number of a table cell was less than 5 .

\section{Results}

A total of 140 patients were included in the study, 130 (92.9\%) had protective antibodies against varicella (Table 1). Although the number of patients included and antibodies prevalence did not allow sophisticated discrimination analysis, this study shows a higher prevalence of susceptible individuals born after 1980 (7/45; 15.5\%) compared to those born before 1980 (3/96; 3.1\%).

\section{Discussion}

In this cross-sectional study, we detected a high prevalence of subjects with antibodies against varicella among adults with no clinical history of disease, especially those born before 1980. Of the three susceptible individuals born before 1980, two were born at the 1950s and had result tests very close to the cut-off score $(125 \mathrm{IU} / \mathrm{mL}$ and $135 \mathrm{IU} / \mathrm{mL})$, and may represent protected individuals with waning antibody titers. Only one individual born in 1970 had a titer antibody $9 \mathrm{IU} / \mathrm{mL}$. He was a healthy traveler, who had only one brother with unknown history of varicella and two children (14 and 4 years old) vaccinated for varicella.

Even though it is well established that the history of varicella has a high positive predictive value for protection, a negative history was not accurate to predict susceptibility in the studied population. Considering that the serology cost is lower (estimate of USD 12.6 in our institution) than two doses of vaccine in the PNI (estimate of USD 35.5 for 2 doses) and immunoglobulin (estimated USD 556.7 for an adult with $60 \mathrm{~kg}$ ), this approach is cost-effective and should be considered for adults in middleincome countries.

\section{Conclusion}

The absence of history of previous varicella episode was not accurate to predict susceptibility in the studied population, a finding consistent with other studies 10. The use of standard serology allowed to indicate immune prophylaxis to varicella in a rational way in a public reference center, with a significant reduction of unnecessary vaccine and immunoglobulin use. Additional studies would help to identify predictor factors associated with immunity such as year of birth to support individual vaccine recommendation. 
Table 1

Seroprevalence of varicella antibodies in the studied population.

\begin{tabular}{|c|c|c|c|c|c|c|c|}
\hline \multirow[t]{2}{*}{ Variables } & \multicolumn{2}{|c|}{$\begin{array}{c}\text { Absence of } \\
\text { protective titers } \\
(n=10 ; 7.1 \%)\end{array}$} & \multicolumn{2}{|c|}{$\begin{array}{c}\text { Presence of } \\
\text { protective titers } \\
(n=130 ; 92.9 \%)\end{array}$} & \multicolumn{2}{|c|}{$\begin{array}{c}\text { Total } \\
(n=140 ; 100.0 \%)\end{array}$} & \multirow[t]{2}{*}{ p-value } \\
\hline & $\mathbf{n}$ & $\%$ & $\mathbf{n}$ & $\%$ & $\mathbf{n}$ & $\%$ & \\
\hline Sex & & & & & & & 0.188 \\
\hline Male & 8 & 80.0 & 72 & 55.4 & 80 & 57.1 & \\
\hline Female & 2 & 20.0 & 58 & 44.6 & 60 & 42.9 & \\
\hline Age in years [average $(S D)]$ & \multicolumn{2}{|c|}{$35.7(12.4)$} & \multicolumn{2}{|c|}{$42.9(13.4)$} & \multicolumn{2}{|c|}{$42.4(13.5)$} & 0.104 \\
\hline Age range (years) & & & & & & & 0.580 \\
\hline $18-25$ & 2 & 20.0 & 17 & 13.1 & 19 & 13.6 & \\
\hline $26-45$ & 6 & 60.0 & 57 & 43.8 & 63 & 45.0 & \\
\hline $46-65$ & 2 & 20.0 & 49 & 37.7 & 51 & 36.4 & \\
\hline $66-75$ & 0 & 0.0 & 7 & 5.4 & 7 & 5.0 & \\
\hline Year of birth & & & & & & & 0.031 \\
\hline 1938 to 1979 & 3 & 30.0 & 90 & 69.2 & 93 & 66.4 & \\
\hline 1980 to 1996 & 7 & 70.0 & 40 & 30.8 & 47 & 33.6 & \\
\hline Resided in rural area & 3 & 30.0 & 34 & 26.2 & 37 & 26.4 & 0.724 \\
\hline Number of siblings [average (SD)] & \multicolumn{2}{|c|}{$2.6(3.2)$} & \multicolumn{2}{|c|}{$4.0(3.0)$} & \multicolumn{2}{|c|}{$3.9(3.0)$} & 0.155 \\
\hline Siblings had varicella & 3 & 33.3 & 34 & 28.1 & 37 & 28.5 & 1.000 \\
\hline Has children & 3 & 30.0 & 79 & 60.8 & 82 & 58.6 & 0.093 \\
\hline Children had varicella & 0 & 0.0 & 38 & 48.1 & 38 & 46.3 & 0.299 \\
\hline Children vaccinated for varicella & & & & & & & 0.191 \\
\hline Yes & 1 & 33.3 & 4 & 5.1 & 5 & 6.1 & \\
\hline No & 2 & 66.7 & 68 & 86.1 & 70 & 85.4 & \\
\hline Ignored & 0 & 0.0 & 7 & 8.9 & 7 & 8.5 & \\
\hline Base condition & & & & & & & 0.615 \\
\hline Healthcare professional & 0 & 0.0 & 4 & 3.1 & 4 & 2.9 & \\
\hline Household contact of immunodeficients & 0 & 0.0 & 4 & 3.1 & 4 & 2.9 & \\
\hline Candidates for immunosuppression due to chronic disease & 1 & 10.0 & 2 & 1.5 & 3 & 2.1 & \\
\hline Candidates for solid organ transplantation & 0 & 0.0 & 12 & 9.2 & 12 & 8.6 & \\
\hline Chronic nephropathies & 0 & 0.0 & 5 & 3.9 & 5 & 3.6 & \\
\hline Bone marrow recipients & 0 & 0.0 & 3 & 2.3 & 3 & 2.1 & \\
\hline Solid organ recipients & 0 & 0.0 & 4 & 3.1 & 4 & 2.9 & \\
\hline HIV & 6 & 60.0 & 64 & 49.2 & 70 & 50.0 & \\
\hline Use of immunosuppressors due to chronic disease & 0 & 0.0 & 3 & 2.3 & 3 & 2.1 & \\
\hline Serious chronic dermatological diseases & 0 & 0.0 & 1 & 0.8 & 1 & 0.7 & \\
\hline Anatomical or functional asplenia & 0 & 0.0 & 11 & 8.5 & 11 & 7.9 & \\
\hline Travelers & 3 & 30.0 & 10 & 7.7 & 13 & 9.3 & \\
\hline Pneumopathy & 0 & 0.0 & 4 & 3.1 & 4 & 2.9 & \\
\hline Cardiopathy & 0 & 0.0 & 1 & 0.8 & 1 & 0.7 & \\
\hline Liver disease & 0 & 0.0 & 2 & 1.5 & 2 & 1.4 & \\
\hline Hemotransfusion in the last 6 months & 0 & 0.0 & 6 & 4.6 & 6 & 4.3 & 1.000 \\
\hline
\end{tabular}




\section{Contributors}

K. S. Büchele and L. G. P. Brandão contributed to the project elaboration, literature review, data collection, statistical analysis, and publication writing. D. F. Correa, M. Tuyama, A. S. Lemos, M. D. Costa, E. C. Mesquita, and D. M. Costa contributed to the data collection, statistical analysis, and publication writing. J. Cerbino-Neto contributed to the literature review, statistical analysis, and publication writing. M. C. Varela contributed to the database elaboration, statistical analysis, and publication writing. P. E. A. A. Brasil contributed to the statistical analysis and publication writing.

\section{Additional informations}

ORCID: Konrad Silva Büchele (0000-0002-57376709); Danusa Ferreira Correa (0000-0002-61216919); Mari Tuyama (0000-0002-0082-5155); Alberto dos Santos de Lemos (0000-0003-01386577); Marcellus Dias da Costa (0000-0003-24935583); Emersom Cicilini Mesquita (0000-00025132-3315); Daniel Marinho da Costa (0000-00018630-3245); José Cerbino-Neto (0000-0001-9254917X); Margareth Catoia Varela (0000-0002-81611158); Pedro Emmanuel Americano Alvarenga do Brasil (0000-0002-6700-2268); Luciana Gomes Pedro Brandão (0000-0002-5271-422X).

\section{Acknowledgments}

We gratefully acknowledge the Immunodiagnostic Laboratory of the National Institute of Infectious Disease Evandro Chagas, Oswaldo Cruz Foundation (INI/Fiocruz) for performing the sorologic tests.

\section{References}

1. Arvin AM. Varicella-zoster virus. Clin Microbiol Rev 1996; 9:361-81.

2. Preblud SR. Age-specific risks of varicella complications. Pediatrics 1981; 68:14-7.

3. Hamborsky J, Kroger A, Wolfe C, editors. Epidemiology and prevention of vaccine-preventable diseases. Centers for Disease Control and Prevention. https://www.cdc.gov/vaccines/ pubs/pinkbook/varicella.html (accessed on 26/Feb/2018).

4. Valentim J, Sartori AMC, de Soárez PC, Amaku M, Azevedo RS, Novaes HM. Costeffectiveness analysis of universal childhood vaccination against varicella in Brazil. Vaccine 2008; 26:6281-91.

5. Meyer PA, Seward JF, Jumaan AO, Wharton M. Varicella mortality: trends before vaccine licensure in the United States, 1970-1994. J Infect Dis 2000; 182:383-90.

6. Coordenação Geral do Programa Nacional de Imunizações, Secretaria de Vigilância em Saúde, Ministério da Saúde. Informe técnico de introdução da vacina tetra viral. Brasília: Ministério da Saúde; 2013.

7. Coordenação Geral do Programa Nacional de Imunizações, Secretaria de Vigilância em Saúde, Ministério da Saúde. Nota Informativa $n^{\circ}$ 135-SEI/2017 - CGPNI/DEVIT/SVS/MS. Informa as mudanças no Calendário Nacional de Vacinação para o ano de 2018. Brasília: Ministério da Saúde; 2018.

8. Departamento de Vigilância das Doenças Transmissíveis, Secretaria de Vigilância em Saúde, Ministério da Saúde. Manual dos Centros de Referência para Imunobiológicos Especiais. 4a Ed. Brasília: Ministério da Saúde; 2014.

9. Holmes CN. Predictive value of a history of varicella infection. Can Fam Physician 2005; 51:60-5.

10. Koturoglu G, Kurugol Z, Turkoglu E. Seroepidemiology of varicella-zoster virus and reliability of varicella history in Turkish children, adolescents and adults. Paediatr Perinat Epidemiol 2011; 25:388-93. 


\section{Resumo}

A varicela é uma doença potencialmente grave em adultos e em pacientes imunocomprometidos. $\mathrm{O}$ diagnóstico clínico da varicela apresenta alta acurácia, e o relato da doença na história individual tem alto valor preditivo positivo para a proteção. Entretanto, uma proporção significativa de adultos, principalmente os mais idosos, não se lembra se já teve a doença. Realizamos um estudo transversal para determinar a soroprevalência de títulos protetores de anticorpos contra a varicela em adultos sem história clínica da doença, atendidos em um Centro de Referência para Imunobiológicos Especiais e Medicina de Viagem no Rio de Janeiro, Brasil. Os títulos da imunoglobulina G (IgG) contra varicela-zoster foram determinados por quimiluminescência. Entre 140 adultos sem história de varicela, 92\% apresentaram titulos protetores de anticorpos. Concluímos que a soroprevalência de proteção contra varicela-zoster é muito alta em adultos sem história da doença, e que o uso de teste sorológico antes da vacinação reduziria significativamente a vacinação desnecessária e o uso de imunoglobulina.

Varicela; Adulto; Soroprevalência; Vacinas

\section{Resumen}

La varicela en adultos y pacientes inmunocomprometidos puede ser grave. El diagnóstico clínico de la varicela tiene una gran precisión y la historia de la enfermedad cuenta con un alto valor predictivo positivo para la protección contra ella. Sin embargo, un porcentaje significativo de adultos, no puede recordar si tuvieron varicela, especialmente las personas más viejas. Realizamos un estudio transversal para determinar la seroprevalencia de las concentraciones de anticuerpos protectores frente a la varicela, en adultos sin historia clínica de la enfermedad, que se llevó a cabo en un Centro de Referencia para Inmunobiología Especial y Medicina del Viajero en Río de Janeiro (Brasil). Se determinó la valoración de los anticuerpos de inmunoglobulina $G(\operatorname{IgG})$ a la varicela-zoster mediante un ensayo inmunológico quimioluminiscente. Entre 140 adultos sin historial de varicela, un 92\% tuvieron concentraciones de anticuerpos protectores. Concluimos que la seroprevalencia de la protección a la varicela-zoster fue muy alta en adultos con un historial negativo de la enfermedad y la utilización de la serología antes de la vacunación redujo de manera significativa la vacunación innecesaria y el uso de la inmunoglobulina.

Varicela; Adulto; Seroprevalencia; Vacunas
Submitted on 16/Aug/2019

Final version resubmitted on 09/Oct/2019

Approved on 25/Oct/2019 